Article

\title{
Governing China's Clean Energy Transition: Policy Reforms, Flexible Implementation and the Need for Empirical Investigation
}

\author{
Kevin Lo \\ Received: 25 August 2015 ; Accepted: 16 November 2015 ; Published: 23 November 2015 \\ Academic Editor: Andy Wright \\ Department of Geography, Hong Kong Baptist University, Kowloon Tong, Hong Kong, China; \\ lokevin@hkbu.edu.hk; Tel.: +852-3411-3397; Fax: +852-3411-5990
}

\begin{abstract}
In the ten years since committing to clean energy transition, China has formulated a large number of policies and programs to achieve some very ambitious targets. This paper argues that the dearth of empirical studies concerning the implementation of these new policies and programs has created a knowledge gap between official policy documents, which are vague and lacking in specifics, and official policy outcomes, which are unreliable. In particular, the merits and limitations of flexible implementation with regard to desirable outcomes need to be debated and clarified. This paper calls for more empirical investigation in four areas as a starting point: (1) the nature and extent of flexibility in the implementation; (2) implementation strategies and their impacts; (3) factors that shape the behavior of local officials responsible for implementation; and (4) the relationship between the central-local relation and policy implementation.
\end{abstract}

Keywords: clean energy transition; policy; flexible implementation; China

\section{Introduction}

Traditionally, the energy system of China has been characterized by a heavy reliance on coal and high energy intensity. Coping with the associated economic and environmental problems, of both a domestic and an international nature, has become a top priority for the government. The 11th Five-Year Plan (2006-2010), in which the goal of reducing national energy intensity by $20 \%$ in five years was announced, marked the beginning of China's clean energy transition. Various other clean energy objectives have since been issued, the latest, to be achieved by 2020, being documented in the Energy Development Strategic Plan (2014-2020). These objectives include limiting energy consumption to 4.8 billion tons of standard coal equivalent (tce), limiting coal consumption to 4.2 billion tons, increasing the proportion of natural gas to $10 \%$, increasing non-fossil-fuel energy to $15 \%$ and reducing the coal proportion to less than $62 \%$ [1]. In the longer term, China has pledged in the United Nations Framework Convention on Climate Change (UNFCCC) to achieve peak carbon emissions by approximately 2030 [2].

Whether and how China will be able to meet these ambitious goals depends on the effective governance of clean energy transition. There is no doubt that, in a relatively short time, the Chinese government has radically changed its priorities from inexpensive energy to clean and renewable energy and from accommodating the growth of energy consumption to constraining energy consumption. This shift in priorities was accompanied by a large number of new clean energy policies and programs. Given the rapidly changing policy context, this paper argues that the lack of empirical research concerning the implementation process has limited our understanding of China's clean energy transition. Consequently, a knowledge gap has been created between official policy documents, which are often vague and lacking in specifics, and official policy outcomes, 
which are unreliable, if not outright impossible. In particular, the recent emphasis on flexible implementation, in the sense that local governments are allowed, and even encouraged, to adapt central directives to suit local conditions, has increased the importance of implementation vis-à-vis policymaking. Consequently, the merits and limitations of flexibility with regards to desirable environmental outcomes need to be debated and clarified.

A better understanding of China's clean energy transition is of international interest for several reasons. First, China is now the world's largest annual energy consumer and greenhouse gas emitter [3]; therefore, the activities of the country have global implications in terms of climate change, energy security, energy trade and the geopolitics of energy. Second, as the world's largest developing country, China's experience can serve as a model for fellow developing countries about to embark on a similar process of clean energy transition. Third, as an emerging world power, China wields significant influence on global climate negotiations; this was apparent during the 2009 Copenhagen Climate Summit $[4,5]$. Countries such as the United States and Australia have used the perceived inaction of China and other developing countries as justification to disregard their own mitigation responsibilities. Consequently, the commitment to clean energy transition demonstrated by China can provide much-needed momentum to the efforts for attaining a constructive and cooperative global solution to climate change.

The remainder of this paper will elaborate on the argument by first describing China's clean energy transition policy from two aspects: energy efficiency and conservation, to reduce energy use through technological and behavioral changes; and renewable and low-carbon energy, to move from fossil fuels to renewable energy (e.g., wind, solar, hydro and geothermal) and low-carbon energy (e.g., nuclear and natural gas). Then, it will examine empirical studies on the implementation process, noting both their strengths and limitations, identify the key debate and suggest certain important research areas for future studies.

\section{Energy Efficiency and Conservation Policy}

China's intention with regard to energy efficiency and conservation was announced by the State Council with its mandatory national target of a 20\% reduction in energy intensity between 2006 and 2010, as well as the revision of the Energy Conservation Law in 2007. To achieve these objectives, the central government has developed a number of new clean energy programs that target the industrial, building and transport sectors.

The most important program supporting industrial energy efficiency and conservation is the Ten Thousand Enterprise Low-Carbon Energy Conservation Programme (Ten Thousand Enterprises Programme), introduced in 2011. This command-and-control program regulates more than 16,000 energy-intensive enterprises that collectively account for $60 \%$ of the country's total energy consumption [6]. It requires these enterprises to achieve certain amounts of energy saving and to implement a number of energy management measures, for which funding of 240-300 CNY/tce $(1 \mathrm{CNY}=0.15 \mathrm{USD}$ ) is provided. The program is thus expected to deliver 250 million tce of energy savings over five years, more than one-third of China's total energy-saving target of 670 million tce.

In addition to the Ten Thousand Enterprises Programme, the central government has prioritized the elimination of a backward-production capacity, that is production equipment and processes that are deemed overly energy intensive and polluting. This policy measure consists of both economic and administrative elements. Under the first, the central government imposes an electricity surcharge of $0.05-0.4 \mathrm{CNY} / \mathrm{kWh}$ on industries that fall within the elimination category $[7,8]$, and local governments are empowered to impose a higher surcharge: for example, in 2015, Beijing increased this surcharge to $0.2-0.5 \mathrm{CNY} / \mathrm{kWh}$ [9]. The second mechanism is forced closure [10], which shuts down a certain amount of old production capacity. The central government does offer compensation to affected enterprises, however, due to the negative impact on the workers. Between 2006 and 2010, the central government paid 21.91 billion CNY in compensation, successfully closing down 
production capacity in relation to 122 million tons of iron, 70 million tons of steel and 330 million tons of cement [11].

Turning to the building sector, the central government initiated a subsidy-based program in 2007 to support the retrofitting of insulation in existing buildings: $55 \mathrm{CNY} / \mathrm{m}^{2}$ in severely cold regions and $45 \mathrm{CNY} / \mathrm{m}^{2}$ in cold regions. This funding can be used for improving the thermal properties of the building envelope (i.e., wall, roof and windows), installing heat meters and improving the efficiency of heat distribution systems. To date, the program has enabled the successful retrofitting of 182 million $\mathrm{m}^{2}$ between 2007 and 2010 and 750 million $\mathrm{m}^{2}$ between 2011 and 2014 [12], making it one of the most successful building-retrofit programs in the world. New buildings in China have to comply with the energy building codes, which set minimum energy-efficiency requirements, and are quite stringent compared to international standards [13]. Enforcement of the energy building codes has also significantly improved recently, with an official compliance rate of $100 \%$ being achieved for the first time in 2010 [14].

With regard to the transport sector, the central government has shown great enthusiasm for promoting electric vehicles, which are regarded as the future [15]. Since 2009, the central government has been offering subsidies to purchase plug-in hybrid and purely electric vehicles. According to the latest update, the subsidy offered is $23,000-55,000 \mathrm{CNY}$ per vehicle, depending on the type; however, this will be reduced by $20 \%$ in $2017 / 2018$ and $40 \%$ in $2019 / 2020$ [16]. An added incentive is that the owners of eligible electric vehicles are exempt from the annual Vehicle and Vessel Tax [17]. However, the effect of these programs has been less than expected, and at the end of 2014, there were only 120,000 new energy vehicles, lagging far behind the 2015 target of 500,000 [18]. This low rate of uptake reflects concerns related to the convenience of charging points, distance limitations, battery longevity and the high price of the vehicles [19]. In addition, tightening of the Fuel Economy Standards has been playing an important role in rendering combustion engine vehicles, which numbered 150 million at the end of 2014, more energy efficient. The Fuel Economy Standards were introduced in 2005 and have since been revised three times. The latest edition, GB 19578-2014 [20], which will be in effect from 2016 to 2020, was designed to improve the fuel economy of new passenger vehicles to $5.0 \mathrm{~L} / 100 \mathrm{~km}$ by 2020. Moreover, generous Vehicle and Vessel Tax incentives are being offered for vehicles that are more efficient than the standards require [17].

\section{Renewable and Low-Carbon Energy Policy}

Since the Renewable Energy Law was passed, followed by the Mid- to Long-Term Development Plan for Renewable Energy in 2007 [21], renewable energy has become a priority for energy development in China. Similar to many other countries worldwide, the rapid development of renewable energy in China is driven mainly by feed-in tariffs. Initially, the level of these tariffs was determined through auctions to encourage competition among the developers. However, this resulted in bidding wars, which was detrimental to the long-term sustainability of the renewable energy industry. Driven by aggressive pricing from state-owned enterprises, the winning bids for wind power during this period ranged from $0.373 \mathrm{CNY} / \mathrm{kWh}$ to $0.519 \mathrm{CNY} / \mathrm{kWh}$, which were clearly unprofitable for the suppliers [22]. In response, a standard feed-in tariff system, ranging from $0.51 \mathrm{CNY} / \mathrm{kWh}$ to $0.61 \mathrm{CNY} / \mathrm{kWh}$ (adjusted to $0.49-0.61 \mathrm{CNY} / \mathrm{kWh}$ in 2015), was introduced in 2009 to replace the auctions for onshore wind generation [23]. This new system has successfully diversified the investment in wind power: by the end of 2013, more than 1300 companies had invested in wind power, with state-owned enterprises accounting for $81 \%$ of the installed capacity, local private enterprises $3.8 \%$, overseas private enterprises $2.6 \%$ and joint ventures $12.7 \%$ [24].

The success of the wind-power feed-in tariff system has encouraged the government to use this policy to support other forms of renewable energy, including: bioenergy in the agricultural sector and forestry in $2010(0.75 \mathrm{CNY} / \mathrm{kWh})$ [25], utility-scale photovoltaics in $2013(0.90-1.00 \mathrm{CNY} / \mathrm{kWh})$ and offshore wind power in $2014(0.75-0.85 \mathrm{CNY} / \mathrm{kWh})$ [26]. Currently, distributed photovoltaics also receive a fixed-rate subsidy of $0.42 \mathrm{CNY} / \mathrm{kWh}$. It should also be noted that several local governments 
have established subsidies that complement the national feed-in tariff in an effort to attract investment in renewable energy: for example, the Shanghai Municipal Government offers a five-year support program for onshore wind-energy generation $(0.1 \mathrm{CNY} / \mathrm{kWh})$, offshore wind-energy generation (0.2 CNY $/ \mathrm{kWh})$ and photovoltaics $(0.25-0.4 \mathrm{CNY} / \mathrm{kWh})$ [27]. The feed-in tariff system in China is financed primarily by the renewable energy surcharge, which is levied nationally, except in the Tibetan Autonomous Region, on all types of electricity consumption. When firstly introduced in 2006, the surcharge was relatively modest at a rate of $0.001 \mathrm{CNY} / \mathrm{kWh}$; however, the rate has since been increased several times, as the collected funds were insufficient to cover the feed-in tariff expenditure. Currently, the levy is $0.015 \mathrm{CNY} / \mathrm{kWh}$, except for residential and agricultural uses, which remain at $0.008 \mathrm{CNY} / \mathrm{kWh}[28]$.

In addition to the feed-in tariff, renewable energy is further supported by tax incentives. The hydroelectricity sector, which does not benefit from feed-in tariffs, is eligible for a value-added tax rebate: $8 \%$ for utility-scale installations and 3\% for small-scale installations, which are substantially lower than the normal $17 \%$ rate $[29,30]$. The wind and solar sectors benefit from a $50 \%$ value-added tax rebate [31,32], while the waste-to-energy sector is eligible for a full rebate [33]. Furthermore, various short-term subsidy programs, often introduced prior to the standard feed-in tariffs, have been implemented to support renewable energy development. For example, from 2009 to 2013, the Golden Sun Demonstration Programme provided grants to large-scale photovoltaics projects, covering $50 \%$ of the cost of normal projects and $70 \%$ for projects in remote areas [34].

Official statistics show that these policies have resulted in a rapid growth in renewable energy, in particular wind and solar power. In 2005, the country had only $1260 \mathrm{MW}$ of installed wind capacity, but by 2014 , this capacity had increased to $95,810 \mathrm{MW}$, representing $31 \%$ of the total global wind capacity [35]. More recently, the solar photovoltaics capacity has been increasing at an equally rapid pace. In 2014, China's photovoltaics capacity had increased by $60 \%$ to $26,520 \mathrm{MW}$, with $4670 \mathrm{MW}$ derived from distributed sources [36]. Overall, the share of renewable energy in the country's total installed capacity has increased from $23 \%$ in 2005 to $32 \%$ in 2014 . However, the curtailment of renewable power, especially wind power, is becoming an endemic problem in China and a key barrier to renewable energy development. The National Energy Administration reported that $17,500 \mathrm{GWh}$ of wind electricity was lost because of curtailment in the first half of 2015 alone [37]. Furthermore, up to $30 \%$ of the installed capacity was unable to obtain access to the grid [38]. In March 2015, the National Development and Reform Committee issued a series of instructions on methods to address the curtailment problem, including: prioritizing renewable energy in the annual electricity-balancing exercise, prioritizing imports of renewable energy for provinces where renewable energy is underdeveloped and providing financial support for regulating coal-fired power peaks [39]. The government intends to introduce renewable portfolio standards in the future, which will impose mandatory targets on local governments to ensure that a certain proportion of electricity consumption is derived from renewable energy sources [40].

The Chinese government has also devised three main strategies relevant to low-carbon energy, namely: (1) promoting nuclear energy; (2) supporting the use of natural gas; and (3) eliminating small and inefficient coal-fired units. Concerning nuclear energy, the release of the Mid- to Long-Term Development Plan for Nuclear Energy (2011-2020) in 2007 marked the beginning of a rapid development of nuclear power in the country. A number of tax incentives were introduced to support this, including a rebate on value-added tax (75\% for the first five years of operation, $70 \%$ for Years 6-10 and 55\% for Years 11-15) [41], as well as a rebate on import tax for essential equipment. Since nuclear power is cost competitive, the demand for this type of energy is high, especially in the coastal areas, where energy endowment is poor [42]. In light of the Fukushima accident in Japan, though, the central government of China has prioritized nuclear safety, and comprehensive inspections of nuclear facilities are therefore conducted [43].

With respect to natural gas, the intention of the government is to increase its use as a substitute for coal in the electricity sector and oil in the transport sector. Consequently, the government 
has recently started implementing a fast-track approval process for gas-fired units [44], while the Ministry of Transport has made funding available for liquefied natural gas projects for road and water transport [45].

China has numerous small and inefficient coal-fired power units, built during the 1980s and 1990s to address the severe electricity shortages at the time. These low-cost, but polluting units need to be replaced with renewable and low-carbon energy plants. In 1999, the central government issued a directive that coal-fired units smaller than $50 \mathrm{MW}$ were to be decommissioned. However, this was not strictly implemented, and by 2006, the capacity of power units smaller than $10 \mathrm{MW}$ was still more than $121 \mathrm{GW}$. A new policy was thus adopted in 2007 aiming to shut down: (1) coal-fired units smaller than $50 \mathrm{MW}$; (2) coal-fired units between $50 \mathrm{MW}$ and $100 \mathrm{MW}$ that had been in operation for 20 years or longer; and (3) coal-fired units between $100 \mathrm{MW}$ and $200 \mathrm{MW}$ that had exceeded their design life [46]. An innovative feature of this policy is bundling the decommissioning of dispensable plants with the approval for constructing new coal-fired power plants. For example, to receive approval from the central government to build a 1000-MW coal-fired power plant, the local authority is obliged to shut down at least $600 \mathrm{MW}$ of small and inefficient units. The government also employs economic measures to achieve its goals, such as lowering the on-grid electricity tariffs of small coal-fired units [47]. This new policy has resulted in a wave of shutdowns, with over $76.8 \mathrm{GW}$ of capacity being eliminated between 2006 and 2010 and a further $20 \mathrm{GW}$ expected to be shut down between 2011 and 2015.

\section{Flexible Implementation}

Recent empirical studies have shed light on a highly complex and varied implementation process of clean energy programs in China. There is clear evidence that, contrary to the common perception of a highly hierarchical and top-down governance approach, the implementation process displays a high degree of flexibility [48,49]. This flexibility is revealed in policy targets, the amount of funding dedicated to implementation and the choice of policy instruments, scope and framing. Furthermore, it reflects the trend for decentralization of the policy process in the post-Mao period. While the central government remains the primary policymaker, it rarely involves itself in the implementation process, which is devolved to local governments. In fact, learning from the disastrous consequences of uniform implementation during the Mao period, the central government now encourages flexible implementation that is sensitive to local contexts.

This de jure flexibility coexists with what can be called de facto flexibility in China. Given the large size of the country, it is difficult for the central government to monitor local government behavior. While China's unitary (as opposed to federal) system gives the central government absolute power over local governments, the ability to exercise this power is constrained by the problem of asymmetric information and the cost involved in tackling it [50,51]. Conflicting priorities from the central government, for example between economic and environmental objectives, further weaken central control over local governments and enhance de facto flexibility in local implementation [52]. Therefore, even if the central government has the intention of tightening up the implementation process, it may lack the means and capability to do so.

While flexibility in the implementation process is a well-known Chinese phenomenon, there is an ongoing debate on whether, how much and what type of flexibility is conducive to desirable outcomes in terms of clean energy transition. Two contrasting viewpoints can be established. On the one hand, flexibility can improve policy implementation by allowing local governments to adapt to local contexts and stimulating policy innovation. There is some evidence to support this viewpoint: with regard to the retrofitting of existing buildings, the local government in Changchun changed the voluntary-based subsidy program to an essentially free, but involuntary retrofit program, resulting in the successful retrofitting of a large number of apartments in a very short period [53]. In another illustrative case, officials responsible for implementing the industrial energy-efficiency programs in Shanxi province were able to increase public support and minimize political resistance 
by policy-bundling: the programs were implemented as part of larger campaigns and connected with policies and concerns of a more local or immediate interest [54]. Furthermore, in Beijing, the government provides additional incentives for purchasing electric vehicles by exempting them from the strict car ownership control program.

On the other hand, flexible implementation can give local governments the opportunity to ignore, distort or undermine central directives, resulting in poor environmental outcomes compared to what the central government intended. There is equally compelling evidence to support this viewpoint, of which the implementation of the Ten Thousand Enterprises Programme in Changchun is an example. Due to cost-cutting in enforcement activities and the refusal to impose penalties on local enterprises that do not comply with the requirements, the local government has changed the mandatory energy-efficiency program into essentially a voluntary one, to the detriment of the program's performance [6]. Moreover, with regard to the elimination of backward-production capacity, many local governments have been caught falsifying the production capacity of the factories that were closed down or closing the same factory multiple times to claim extra credit.

Such conflicting views about China's flexible implementation of a clean energy policy cannot be adequately resolved without more empirical evidence and fine-grained analysis. In particular, several knowledge gaps must be addressed. First, there is a need to establish the nature and extent of flexibility in implementation: To what degree can local government deviate from central directives? In what ways? Where are the boundaries? How does the situation vary across different policy areas and programs? It is important to be mindful that implementation is a complex process, and there are many aspects of flexibility (targets, instruments, funding, etc.), which raises the question of which components should be made flexible. Past experience suggests that the central government typically allocates a high degree of flexibility in the amount of funding and policy instruments, but not with policy targets. Such an approach, however, has given rise to the phenomenon of meeting targets with methods that are detrimental to the long-term objectives. For example, in the latter half of 2010, many factories were shut down temporarily by local governments to reduce their emissions, without any long-term measures for energy-efficiency improvement.

Second, there is the form implementation strategies have taken in the context of flexible implementation: Do local governments adapt central directives to local contexts or, rather, use flexibility as an excuse for refusing to carry out their implementation responsibilities fully? What innovative strategies have been developed by local officials? Are they successful? Can the experience be transferred elsewhere? To answer these questions, we need empirical observation of the types of implementation strategies that have been adopted by local governments. It is also necessary to collect independent empirical evidence on the outcome of clean energy policy implementation. Many existing studies rely solely on official data, but such an over-reliance on government data is problematic, given the concerns about reliability and accuracy, including: evidence of data manipulation at both central and local levels, the lack of data in some crucial areas and the differences in terminologies and definitions [55]. Studies should not ignore the unintended consequences of implementing these policies either, in particular with regard to the people affected. For instance, shutting down small coal-fired units and backward-production capacity severely affects the livelihoods of a large number of people. Understanding the impact and how the government can assist with the transition are therefore important and valuable research endeavors.

Third, we need to explain the differences in approach to implementation, which involves asking such questions as: How do local officials determine implementation priorities? What are the factors and actors that shape such decisions? Why can a program be implemented well in one place, but not in another? Existing studies generally point to local interests as a crucial factor. The new role of local governments as a champion of local interests is a product of the post-Mao financial reforms that transferred greater financial responsibility to localities. Local officials now have great incentives to strengthen local economies to maintain a steady revenue. Moreover, intense competition between localities provides a huge motivation to local officials vying for promotion, which further strengthens 
the incentive to advance local interests. As a result, clean energy policies that are aligned more with local interests will receive more attention from the local government. While this argument is convincing, local interests are not the only determining factor, as there are many cases where local officials implement policies that ostensibly harm local interests. A more comprehensive explanation is needed, especially for the causes of poor implementation, which cannot be simply explained away by a lack of local interest. There is a need for a more systematic and multidimensional examination of the factors that shape the behavior of local officials, including local politics, institutional capacities and implementation challenges.

Fourth and finally, the way in which the central government governs the behavior of local government plays an important role in defining the flexibility of implementation. In particular, the role of the target responsibility system in clean energy transition must be better understood, as it has been shown to be an important instrument used by the central government to influence local implementation in the reform era [48]. In short, the target responsibility system establishes political incentives (e.g., promotion, annual honors) for local governments to implement certain programs or meet certain targets. How does the target responsibility system work in the context of clean energy transition? What kind of leverage can the central government apply to ensure compliance from local governments? What are the limitations? How can the central government overcome the asymmetric information problem that has limited its control over local governments? At what cost? More research is therefore needed to produce recommendations with regard to strengthening the ability of the central government to influence the implementation process.

\section{Conclusions}

In the context of China's rapid clean energy transition and its global implications, this paper has underscored a significant gap in knowledge generated by the emergence of numerous new clean energy policies and a dearth of empirical studies on their implementation. Existing studies have identified policy implementation and flexibility in the process as key features of and challenges to China's clean energy transition. However, questions regarding the nature and extent of flexibility in implementation, implementation strategies and their impacts, factors that shape the behavior of local officials responsible for implementation and the relationship between central-local relations and policy implementation need to be addressed. Answering these questions through empirical investigation can contribute to China's clean energy transition in many ways. At a local level, the findings can be used to generate context-specific recommendations for local governments to improve the implementation of clean energy policies. At the national level, the investigation can contribute to the debate on the relationship between flexible implementation and environmental outcomes, as well as help devise a governance system where the implementation process works toward, rather than against, China's important mission of clean energy transition.

Acknowledgments: This research was supported by the Faculty Research Grant of Hong Kong Baptist University (FRG1/14-15/019).

Conflicts of Interest: The authors declare no conflict of interest.

\section{References}

1. State Council. Energy Development Strategic Plan (2014-2020). 2014. Available online: http://www. gov.cn/zhengce/content/2014-11/19/content_9222.htm (accessed on 25 August 2015).

2. National Development and Reform Commission. Enhanced Actions on Climate Change: China's Intended Nationally Determined Contributions. 2015. Available online: http:/ /www4.unfccc.int/submissions/INDC/ Published\%20Documents/China/1/China's\%20INDC\%20-\%20on\%2030\%20June\%202015.pdf (accessed on 25 August 2015).

3. Guan, D.; Liu, Z.; Geng, Y.; Lindner, S.; Hubacek, K. The gigatonne gap in China's carbon dioxide inventories. Nat. Clim. Chang. 2012, 2, 672-675. [CrossRef] 
4. Christoff, P. Cold climate in Copenhagen: China and the United States at COP15. Environ. Polit. 2010, 19, 637-656. [CrossRef]

5. Conrad, B. China in Copenhagen: Reconciling the "Beijing climate revolution" and the "Copenhagen climate obstinacy". China Q. 2012, 210, 435-455. [CrossRef]

6. Lo, K.; Li, H.; Wang, M. Energy conservation in China's energy-intensive enterprises: An empirical study of the Ten-Thousand Enterprises Program. Energy Sustain. Dev. 2015, 27, 105-111. [CrossRef]

7. National Development and Reform Commission. Notice on Using Pricing Mechanisms to Promote the Structural Adjustment of the Cement Industry. 2014. Available online: http://www.sdpc.gov.cn/ fzgggz/jggl/zcfg/201405/t20140520_615511.html (accessed on 25 August 2015).

8. State Council. Opinion on Improving the Electricity Tariff Differentiation Policy. 2006. Available online: http:/ /www.gov.cn/zwgk/2006-09/22/content_396258.htm (accessed on 25 August 2015).

9. Beijing Municipal Commission of Development and Reform. Opinion on Improving the Electric Tariff Differentiation Policy in Beijing. 2015. Available online: http://www.bjpc.gov.cn/tztg/ 201507/t9232987.htm (accessed on 25 August 2015).

10. Ministry of Industry and Information Technology. Notice on the Elimination of Backward Production Capacity Implementation Plan. 2011. Available online: http://www.miit.gov.cn/n11293472/n11293877/ n13138101/n13138148/13583247.html (accessed on 25 August 2015).

11. National Development and Reform Committee. 11th FYP Energy Conservation Review: Significant Results for the Elimination of Backward Production Capacity Programme. 2011. Available online: http:/ /www.gov.cn/gzdt/2011-03/10/content_1821724.htm (accessed on 25 August 2015).

12. Ministry of Housing and Urban-Rural Development. Notice on 2010 Building Energy Conservation Inspection Result. 2010. Available online: http://www.mohurd.gov.cn/zcfg/jsbwj_0/jsbwjjskj/ 201104/t20110421_203196.html (accessed on 25 August 2015).

13. Lee, W.; Chen, H. Benchmarking Hong Kong and China energy codes for residential buildings. Energy Build. 2008, 40, 1628-1636. [CrossRef]

14. Zhou, N.; McNeil, M.; Levine, M. Assessment of building energy-saving policies and programs in China during the 11th five-year plan. Energy Effic. 2012, 5, 51-64. [CrossRef]

15. Liu, Y.; Kokko, A. Who does what in China's new energy vehicle industry? Energy Policy 2013, 57, $21-29$. [CrossRef]

16. Ministry of Finance. Notice on 2016-2020 Fiscal Support Policy for New Energy Vehicles. 2015. Available online: http://jjs.mof.gov.cn/zhengwuxinxi/zhengcefagui/201504/t20150429_1224515.html (accessed on 25 August 2015).

17. Ministry of Finance. Notice on the Vehicle and Vessel Tax Concession for Energy Efficient and New Energy Vehicles and Vessels. 2015. Available online: http://www.chinatax.gov.cn/n810341/n810755/ c1617349/content.html (accessed on 25 August 2015).

18. Xinhua News Agency. China's New Energy Vehicles Ownership Passed 120,000. 2015. Available online: http:/ / news.xinhuanet.com/finance/2015-03/12/c_1114622428.htm (accessed on 25 August 2015).

19. Lo, K. Interested but unsure: Public attitudes toward electric vehicles in China. Electron. Green J. 2013, 36, $1-12$.

20. Standardization Administration. GB 19578-2014 Fuel Consumption Limits for Passenger Cars. 2014. Available online: http://gb123.sac.gov.cn/gb/showGb?gbCode=GB\%2019578-2014 (accessed on 25 August 2015).

21. National Development and Reform Commission. Mid- to Long-Term Development Plan for Renewable Energy. 2007. Available online: http://www.china.com.cn/policy/txt/2007-09/04/content_8800358.htm (accessed on 25 August 2015).

22. Lema, A.; Ruby, K. Between fragmented authoritarianism and policy coordination: Creating a Chinese market for wind energy. Energy Policy 2007, 35, 3879-3890. [CrossRef]

23. National Development and Reform Commission. Notice on Optimising Wind Power Feed-in Tariff Policy. 2009. Available online: http://www.sdpc.gov.cn/zwfwzx/zfdj/jggg/dian/200907/t20090727_292837.html (accessed on 25 August 2015).

24. BeiJiXing. China's Key Wind Power Developers. 2014. Available online: http://news.bjx.com.cn/html/ 20141212/572965.shtml (accessed on 25 August 2015). 
25. National Development and Reform Commission. Notice on Improving Agriculture and Forestry Feed-in Tariff Policy. 2010. Available online: http://www.ndrc.gov.cn/zwfwzx/zfdj/jggg/dian/ 201007/t20100728_363366.html (accessed on 25 August 2015).

26. National Development and Reform Commission. Notice on Offshore Wind Power Feed-in Tariff Policy. 2014. Available online: http://www.sdpc.gov.cn/zwfwzx/zfdj/jggg/dian/201406/t20140619_615708.html (accessed on 25 August 2015).

27. Shanghai Municipal Development and Reform Commission. Shanghai Renewable and New Energy Development Support Fund. 2014. Available online: http://www.shdrc.gov.cn/main?main_colid= 319\&top_id=312\&main_artid=24296 (accessed on 25 August 2015).

28. Ministry of Finance. Notice on Adjusting Renewable Energy Surcharge Standard. 2013. Available online: http://zhs.mof.gov.cn/zhengwuxinxi/zhengcefabu/201310/t20131009_996652.html (accessed on 25 August 2015).

29. Ministry of Finance; State Administration of Taxation. Notice on Utility-Scale Hydroelectricity Value-Added Tax Policy. 2014. Available online: http://202.108.90.131/SuniT/202.108.90.130/ n810341/n810755/c1149889/content.html (accessed on 25 August 2015).

30. Ministry of Finance; State Administration of Taxation. Notice on Simplifying Value-Added Tax Policy. 2014. Available online: http://www.chinatax.gov.cn/n810341/n810755/c1150435/content.html (accessed on 25 August 2015).

31. Ministry of Finance; State Administration of Taxation. Notice on Photovoltaics Power Value-Added Tax Policy. 2013. Available online: http://www.chinatax.gov.cn/n810341/n810765/n812146/n812323/ c1080750/content.html (accessed on 25 August 2015).

32. Ministry of Finance; State Administration of Taxation. Notice on Wind Power Value-Added Tax Policy. 2015. Available online: http://szs.mof.gov.cn/zhengwuxinxi/zhengcefabu/201506/ t20150616_1256851.html (accessed on 25 August 2015).

33. Ministry of Finance; State Administration of Taxation. Notice on Resources Utilisation and Other Products Value-Added Tax Policy. 2008. Available online: http://www.chinatax.gov.cn/n810341/n810765/ n812171/n812675/c1190512/content.html (accessed on 25 August 2015).

34. Ministry of Finance; Ministry of Science and Technology; National Energy Administration. Notice on the Implementation of the Golden Sun Demonstration Programme. 2009. Available online: http://big5.gov.cn/gate/big5/www.gov.cn/zwgk/2009-07/21/content_1370811.htm (accessed on 25 August 2015).

35. Global Wind Report Annual Market Update 2014; Global Wind Energy Council: Brussels, Belgium, 2015; Available online: http://www.gwec.net/wp-content/uploads/2015/03/GWEC_Global_Wind_2014_ Report_LR.pdf (accessed on 25 August 2015).

36. National Energy Administration. Statistics of Photovoltaics Power in 2014. 2015. Available online: http://www.nea.gov.cn/2015-03/09/c_134049519.htm (accessed on 25 August 2015).

37. National Energy Administration. Operation of Wind Power in the First Half of 2015. 2015. Available online: http://www.nea.gov.cn/2015-07/27/c_134451678.htm (accessed on 25 August 2015).

38. Zhao, X.; Zhang, S.; Yang, R.; Wang, M. Constraints on the effective utilization of wind power in China: An illustration from the northeast China grid. Renew. Sustain. Energy Rev. 2012, 16, 4508-4514. [CrossRef]

39. National Development and Reform Commission. Opinions on Improving the Balancing of Electricity to Achieve Full Utilisation of Renewable Energy. 2015. Available online: http://www.sdpc.gov.cn/gzdt/ 201503/t20150323_668207.html (accessed on 25 August 2015).

40. China Energy News. Renewable Energy Portfolio Almost Ready. 2015. Available online: http:// paper.people.com.cn/zgnyb/html/2015-04/20/content_1556462.htm (accessed on 25 August 2015).

41. Ministry of Finance; State Administration of Taxation. Notice on Taxation Policy of the Nuclear Power Industry. 2008. Available online: http://www.chinatax.gov.cn/n810341/n810755/c1224064/content.html (accessed on 25 August 2015).

42. Xu, Y. The struggle for safe nuclear expansion in China. Energy Policy 2014, 73, 21-29. [CrossRef]

43. Mu, R.; Zuo, J.; Yuan, X. China's approach to nuclear safety-From the perspective of policy and institutional system. Energy Policy 2015, 76, 161-172. [CrossRef] 
44. National Development and Reform Commission; National Energy Administration; Ministry of Housing and Urban-Rural Development. Notice on Natural-Gas Distributed Power Demonstration Project Implementation Detail. 2014. Available online: http://www.chinade.org.cn/upload/accessory/ 201411/20141151536383771275.pdf (accessed on 25 August 2015).

45. Ministry of Transport. Instruction on Advancing the Use of Liquefied Natural Gas in Water Transportation. 2013. Available online: http://www.mot.gov.cn/zfxxgk/bnssj/syj/201311/t20131104_1507474.html (accessed on 25 August 2015).

46. State Council. Opinion on Expediating the Elimination of Small Coal-Fired Units. 2007. Available online: http://www.sdpc.gov.cn/zcfb/zcfbqt/200701/t20070131_115037.html (accessed on 25 August 2015).

47. National Development and Reform Commission. Notice on Lowering On-Grid Electricity Tariff of Small Coal-Fired Power Units. 2007. Available online: http://www.sdpc.gov.cn/zwfwzx/zfdj/jggg/ dian/200704/t20070405_128800.html (accessed on 25 August 2015).

48. Lo, K. China's low-carbon city initiatives: The implementation gap and the limits of the target responsibility system. Habitat Int. 2014, 42, 236-244. [CrossRef]

49. He, J. Governing forest restoration: Local case studies of sloping land conversion program in southwest China. For. Policy Econ. 2014, 46, 30-38. [CrossRef]

50. Zheng, Y. De Facto Federalism in China: Reforms and Dynamics of Central-Local Relations; World Scientific Publishing Company: Hackensack, NJ, USA, 2007.

51. Li, L.C. Central-local relations in the People's Republic of China: Trends, processes and impacts for policy implementation. Public Adm. Dev. 2010, 30, 177-190. [CrossRef]

52. Ran, R. Perverse incentive structure and policy implementation gap in China's local environmental politics. J. Environ. Policy Plan. 2013, 15, 17-39. [CrossRef]

53. Lo, K. The "warm houses" program: Insulating existing buildings through compulsory retrofits. Sustain. Energy Technol. Assess. 2015, 9, 63-67. [CrossRef]

54. Kostka, G.; Hobbs, W. Local energy efficiency policy implementation in China: Bridging the gap between national priorities and local interests. China Q. 2012, 211, 765-785. [CrossRef]

55. Sinton, J.E. Accuracy and reliability of China's energy statistics. China Econ. Rev. 2001, 12, $372-383$. [CrossRef]

(C) 2015 by the author; licensee MDPI, Basel, Switzerland. This article is an open access article distributed under the terms and conditions of the Creative Commons by Attribution (CC-BY) license (http://creativecommons.org/licenses/by/4.0/). 